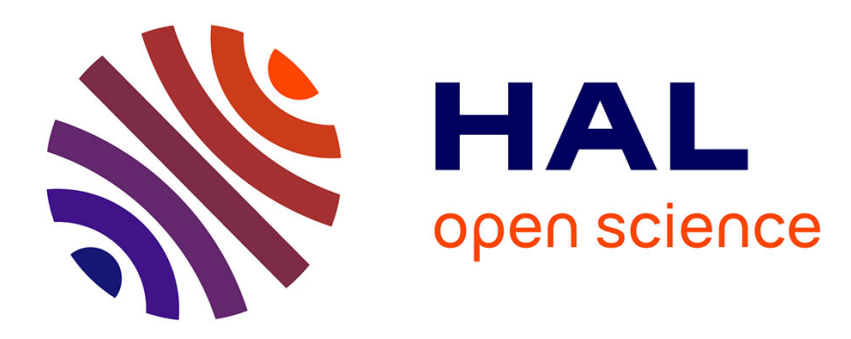

\title{
Compensation in undoped and halogen doped CdTe crystals
}

R. Stuck, A. Cornet, P. Siffert

\section{To cite this version:}

R. Stuck, A. Cornet, P. Siffert. Compensation in undoped and halogen doped CdTe crystals. Revue de Physique Appliquée, 1977, 12 (2), pp.218-218. 10.1051/rphysap:01977001202021800 . jpa-00244146

\section{HAL Id: jpa-00244146 https://hal.science/jpa-00244146}

Submitted on 1 Jan 1977

HAL is a multi-disciplinary open access archive for the deposit and dissemination of scientific research documents, whether they are published or not. The documents may come from teaching and research institutions in France or abroad, or from public or private research centers.
L'archive ouverte pluridisciplinaire HAL, est destinée au dépôt et à la diffusion de documents scientifiques de niveau recherche, publiés ou non, émanant des établissements d'enseignement et de recherche français ou étrangers, des laboratoires publics ou privés. 


\title{
COMPENSATION IN UNDOPED AND HALOGEN DOPED CdTe CRYSTALS
}

\author{
R. STUCK, A. CORNET and P. SIFFERT
}

Centre de Recherches Nucléaires

Laboratoire de Physique des Rayonnements et d'Electronique Nucléaire 67037 Strasbourg cedex, France

\begin{abstract}
Résumé. - On propose un modèle théorique permettant de calculer la concentration de défauts existant dans le tellurure de cadmium non dopé et compensé par un halogène lorsque les cristaux sont préparés par THM. Toutes les associations ainsi que les réactions d'ionisation des défauts sont décrites par la loi d'action de masse. Les énergies d'ionisation des défauts sont déduites des derniers résultats expérimentaux relatifs au diagramme des niveaux dans la bande interdite. Les concentrations des différents types de défauts calculées, pour le matériau dopé au chlore, sont en bon accord avec les valeurs mesurées pour la technique du temps de vol.
\end{abstract}

\begin{abstract}
A theoretical model is proposed which allows the calculation of the concentration of defects in pure and halogen compensated cadmium telluride grown by the THM method. All associations and ionization reactions are described in terms of the law of mass action. The ionization energies of the defects are taken from the energy level diagram established by taking into account the latest experimental data. The concentrations of the different defects calculated for chlorine doped material are in good agreement with that measured using a time of flight method.
\end{abstract}

Un article détaillé a paru sur ce sujet dans le Journal of Physics and Chemistry of Solids 37 (1976) 989. 